\title{
AN INVESTIGATION INTO THE IMPACT OF SERVICE QUALITY, FREQUENT FLIER PROGRAMS AND SAFETY PERCEPTION ON SATISFACTION AND CUSTOMER LOYALTY IN THE AIRLINE INDUSTRY IN SOUTHERN AFRICA
}

Maxwell Sandada, Bright Matibiri

\section{Abstract}

This study aims to identify the factors that make passengers loyal to an airline in Southern Africa by investigating the impact of service quality and safety perception on customer satisfaction and how satisfaction and frequent flyer programs (FFP) subsequently influence customer loyalty. The key finding was that service quality positively influenced customer satisfaction, and satisfaction was an important antecedent of customer loyalty. The analysis also suggested that safety perception and FFP positively influence customer loyalty, while their relationship with satisfaction was not significant. An analysis of switching behaviour revealed that satisfied customers may still switch to other airlines. The main contribution of this study is the development of a customer loyalty model for the aviation industry in Southern Africa. Knowledge of customer loyalty drivers will assist airline marketing managers in developing strategies for improving passenger load factors and profitability.

Key words: Customer loyalty, satisfaction, service quality, safety, frequent flier programmes, aviation.

JEL: $M 31 ; N 77$.

\section{INTRODUCTION}

Increasing competition, the rise of digital technologies such as the Internet and more informed consumers in today's aviation industry implies that airlines must do more to satisfy and retain customers if they are to remain profitable and survive. It is in the airlines' best interest to develop systematic ways of identifying and measuring the factors that shape customer satisfaction and loyalty. Gounaris and Stathakopoulos (2004) assert that loyal consumers have fewer reasons to engage in a comprehensive search for information among different alternatives, thus reducing the propensity to substitute and the probability of switching to alternative choices offering similar performance. Some researchers have suggested that customer acquisition costs five times more than the cost of satisfying and retaining customers, while empirical studies in the US show that a 5 percent increase in customer retention rate can increase profit by between 25 and 95 percent depending on the type of industry (Reichheld, 2001). By dissecting the microeconomic forces that link loyalty to profits, Reichheld and Teal (1996) demonstrated that the high costs of acquiring customers render most customer relationships

Maxwell Sandada, Phd

Senior Lecturer

University of Zimbabwe

Email:msandada@commerce.uz.ac.zw

\section{Bright Matibiri}

MBA student

University of Zimbabwe

Email: bmatibiri@ecbinternational.biz 
unprofitable during the early stages of the customer life cycle.

The key challenges facing the airline business include the volatility of fuel prices, the danger of overcapacity and an increase in labor and maintenance costs. According to IATA data, labor and maintenance costs, which constitute the largest non-fuel expenses, have been steadily rising since 2009 , thus reducing operating margins for airlines (IATA 2014). The profitability of African Airlines has also been negatively impacted by weak load factors, which on average are the lowest in the world and a reflection that the region's airlines are struggling to match capacity with demand (CAPA, 2012).

Oliver (1997) argues that customer loyalty is a key driver of profitability, yet little is known about what drives customer loyalty in the airline business in Southern Africa. Extant literature has mainly been confined to more mature markets in Europe, Australia, the Americas and Asia. Airlines in Southern Africa do not appear to benefit from customer loyalty, as evidenced by weak passenger load factors noted by CAPA reports (CAPA, 2012). Differences in culture, consumer behaviour and income levels between different continents make it very difficult to generalize the findings of extant literature to the predominantly developing countries in Southern Africa. This research is also motivated by the need for further research into loyalty drivers in light of declining loyalty in the airline industry as a result of fierce competition driven by online comparison engines and social media platforms that allow passengers to share experiences. The worsening financial positions of airlines in Southern Africa is a threat to their long term viability and makes it reasonable to look for ways of retaining customers as a way of improving their profitability and ensuring long term survival. If airline managers are aware of customer loyalty drivers they can use such information to make effective decisions on resource allocation and the crafting of marketing strategies that give their airlines sustainable competitive advantage. This paper aims at improving our understanding of the factors that make passengers loyal to an airline by proposing and testing a conceptual framework that includes service quality, safety perception, satisfaction, FFPs and customer loyalty.

The rest of the paper is structured as follows: first, a literature review, hypotheses and the conceptual framework will be presented. This will be followed by the research methodology, data analysis and conclusions. The managerial implications, limitations and recommendations for future research will form the last part of the article.

\section{LITERATURE REVIEW}

\subsection{Customer Loyalty}

Customer loyalty is an important element of organizational success and profitability, because consumers that demonstrate the highest levels of loyalty towards a service are more inclined to repurchase the service more often and spend more (Dehghan and Shahin, 2011). Also, as alluded to by Gómez, Arranz and Cillán (2006), loyal customers are more attractive for firms because they tend to be less price-sensitive and do not require much effort to communicate with than people with no prior experience with the company. Retaining profitable and frequent fliers is an attractive proposition for every airline because businesses succeed by getting, retaining, and growing customers (Kotler and Keller, 2012; Peppers \& Rogers, 2005).

Dehghan and Shahin (2011) identified five dimensions of loyalty from services literature: namely, repeat purchase of a service, resistance to switching, provision of positive word-of-mouth, identifying with a service and preference for a particular service provider. This study uses the term customer loyalty as opposed to brand loyalty, so as to emphasize that loyalty is a characteristic of people as opposed to being something that is inherent in brands (Uncles, Dowling and Hammond, 2003).

A number of studies have focused on identifying effective methods of enhancing loyalty in the services industry, including the use of FFPs to reward repeat purchases as a way of capturing a greater share of consumers' spending (Meyer-waarden, 2008; Lewis, 2004). Other studies identified service quality as a key determinant of customer loyalty, either directly or via the mediating effects of other constructs such as satisfaction (Park, Robertson and Cheng-Lung, 2005). In the same vein, other researchers have shown that corporate image significantly and positively impacts customer loyalty (Kandampully and $\mathrm{Hu} 2007$; Kandampully and Suhartanto 2000). Han, Kwortnik and Wang (2008) carried out a study across service contexts including airlines and hotels and concluded that the key determinants of loyalty are service quality, service fairness, customer satisfaction, commitment and trust. Dolnicar, Grabler, Grun and Kulnig (2011), however, conclude that the drivers of behavioral airline loyalty vary for different market segments, 
thus highlighting the need for marketing managers to develop customized offerings for each segment.

\subsection{Customer Satisfaction}

Szczepańska and Gawron (2011) highlight that a customer's level of satisfaction with a product/service they have purchased is shaped by his/her subjective evaluation of the product/service, the value of the benefits they have received and the customer's overall interaction with the company. Services literature considers customer satisfaction to be one of the most significant outcomes of all marketing activities in any company that is market-oriented (Kandampully \& Suhartanto, 2000).

Angelova and Zekiri (2011) argue that satisfied customers are the foundation of successful businesses because they lead to repeat purchases, positive word of mouth and customer loyalty. Customer loyalty can be a result of high switching barriers or a lack of close substitutes, while in some instances customers are persuaded to continue the relationship because they are satisfied with the product or service (Dehghan \& Shahin, 2011). In the airline industry, where exit barriers are limited and alternatives exist, customer satisfaction is one of the key mechanisms that can be used to keep existing customers, and as such any discussion on loyalty should include a comprehensive analysis of customer satisfaction (Szczepańska \& Gawron, 2011).

Satisfaction is widely acknowledged as a predictor of customer loyalty by a number of empirical studies (Cheng \& Rashid, 2013; Wong \& Sohal, 2003; Eggert \& Ulaga, 2002; Gures et al., 2014). Other researchers (Bowen \& Chen, 2001), however, conclude that the relationship between customer satisfaction and customer loyalty is nonlinear and asymmetric, with loyalty increasing exponentially beyond a certain level of satisfaction and equally falling dramatically when satisfaction declined beyond a certain point. Other studies also noted that customers may still defect even after indicating that they are satisfied with a service provider. For example, Chandrashekaran, Rotte, Tax and Grewal (2007) concluded that satisfaction strength is a key driver in translating satisfaction into loyalty and argued that satisfaction translated into loyalty when it is strongly held, while weakly held satisfaction makes customers vulnerable to defection.

Davis and Heineke (1998) argued that while high levels of satisfaction do not necessarily translate into customer loyalty, dissatisfied customers are likely to search for alternatives or reduce purchase frequency. Although there is no consensus in literature on the relationship between satisfaction and loyalty, a paper by Jan, Abdullah and Smail (2013) highlight that a number of studies carried out in the airline context provide evidence of a positive correlation between customer satisfaction and loyalty. Given this background the following hypothesis is proposed:

H1: Customer satisfaction has a positive effect on customer loyalty.

\subsection{Service quality}

Caruana (2002) highlights that service quality has been a subject of extensive interest from researchers and practitioners alike because they believe that it improves the profitability of a firm. Cheng and Rashid (2013) assert that managing service quality implies that a service provider has to match the service performance with the perceived service in order to achieve customer satisfaction. Also as alluded to by Kotler and Keller (2012), service quality expectations play a big part in customer satisfaction formation. Companies attain acceptable levels of satisfaction by providing services that not only meet customer expectations but exceed them. Several empirical studies reveal the importance of service quality in influencing satisfaction and loyalty. For example Cheng and Rashid (2013) investigate the impact of service quality on customer satisfaction and how customer satisfaction subsequently affects customer loyalty in the hospitality industry. The researchers concluded that a positive relationship exists between service quality and the level of customer satisfaction leading to customer loyalty.

Park et al. (2005) conclude that service quality elements for the airline industry can be categorized into three dimensions: "Reliability and customer service", "Convenience and accessibility" and "Inflight service." The study also concludes that significant positive relationships exist between the dimensions of "Convenience and accessibility", "Inflight service" and airline image, while airline image subsequently influenced behavioral intentions. Jan et al. (2013) come up with a validation model to test the same dimensions of service quality developed by Park et al. (2005) and conclude that all three service quality constructs play a significant role in explaining airline loyalty, particularly in the airline industry in Malaysia. In the same vein Lovelock and Wirtz (2010) argue that service quality is a key input in satisfying customers and that satisfaction forms the basis for developing a loyal customer base. On the strength of findings of these prior studies, the following hypotheses are proposed: 
H2: Service quality measured by reliability, customer service, convenience, accessibility and inflight service has a positive effect on customer satisfaction.

\subsection{Frequent flier programs}

A customer loyalty program is a well-coordinated membership-based marketing strategy designed to provide incentives to customers in order to strengthen continued marketing exchanges with customers and secure their allegiance (Gómez et al., 2006; Lacey \& Sneath, 2006). Firms in travel related industries such as airlines offer customer loyalty programs (referred to as Frequent Flyer programs - FFPs) to encourage repeat purchasing thereby improving customer retention rates by offering incentives for customers to purchase more regularly and in larger volumes (Lewis, 2004).

A number of studies confirm the importance of FFPs in influencing airline preference and customer loyalty (Hess, Adler \& Polak, 2007; Lederman, 2007; Lewis, 2004). By dissecting research data into customer segments, Dolnicar et al. (2011) conclude that loyalty programs are strongly correlated with behavioral loyalty for business and frequent travellers, while the relationship was weak for casual and leisure travellers. Loyalty program privileges are mostly attained by frequent fliers in particular business travellers, and hence there is low interest in such programmes among casual and leisure travellers. Frequent flyer programs also influence habit formation for airline passengers because they increase switching costs for customers (Carlsson \& Lofgren, 2006).

Liu (2007) investigated the long term effectiveness of loyalty programs by conducting a longitudinal study and concludes that these programs positively influenced purchase frequencies and transaction sizes for both light and moderate buyers, making them more loyal. After taking these arguments into account, the following additional hypothesis is proposed:

H3: FFPs positively influence customer loyalty.

\subsection{Safety Perception}

Safety is regarded as an important consideration in passenger airline choice (Gilbert \& Wong, 2003; Wessels, 2006). The observed declines in air passenger numbers following the September 11 attacks in the US also confirm the influence of safety on consumer behavior. Also as alluded to by Ringle, Sarstedt, Zimmermann (2011), airline disasters receive extensive media coverage, implying public awareness of such events. Examining the impact of an airline's safety perception therefore becomes an important consideration in the context of developing long term customer relationships given the potential destabilizing effect safety failures may have on airline selection. Despite the airline industry's claim that safety "has always been the top priority" of the industry and the various measures being put in place to ensure increased passenger safety (IATA, 2014), the occurrence of air accidents cannot be eliminated completely as witnessed by three major airline disasters in 2014 involving Malaysia-based airliners.

Factual airline safety levels are difficult to access (Ringle et al., 2011), therefore passengers resort to proxy measures of safety such as an airline's service quality or their perceptions of an aircraft's appearance (Rhoades \& Waguespack, 2000). The literature reviewed indicates that safety is an important consideration in airline choice (Oyewole, Sankaran \& Choudhury, 2007; Gilbert \& Wong, 2003). On the other hand, the literature is silent on the impact of safety perception on airline image and customer loyalty. Only one study by Ringle et al. (2011) investigated the impact of perceived safety on customer satisfaction, with the purpose of travel as a moderating variable. The research concludes that perceived safety is one of the key drivers of overall customer satisfaction, and the relationship was stronger for leisure travellers than business travellers. Based on the strength of this argument the following hypothesis is proposed:

H4: Safety perception has a positive effect on satisfaction.

\section{CONCEPTUAL FRAMEWORK}

This study builds on extant literature that investigated factors influencing airline customer loyalty and passenger's behavioral intentions (Gures et al., 2014; Jan et al., 2013; Dolnicar et al., 2011; Park et al., 2005). The researchers propose the conceptual framework in Fig. 1 below for testing the hypothesized relationships through empirical research.

\section{METHODOLOGY}

\subsection{Research design}

This study operationalized seven variables, namely FFPs, three service quality dimensions, safety perception, satisfaction and customer loyalty, to test the hypothesized relationships. The researchers carried 
Figure 1: Conceptual framework for the study

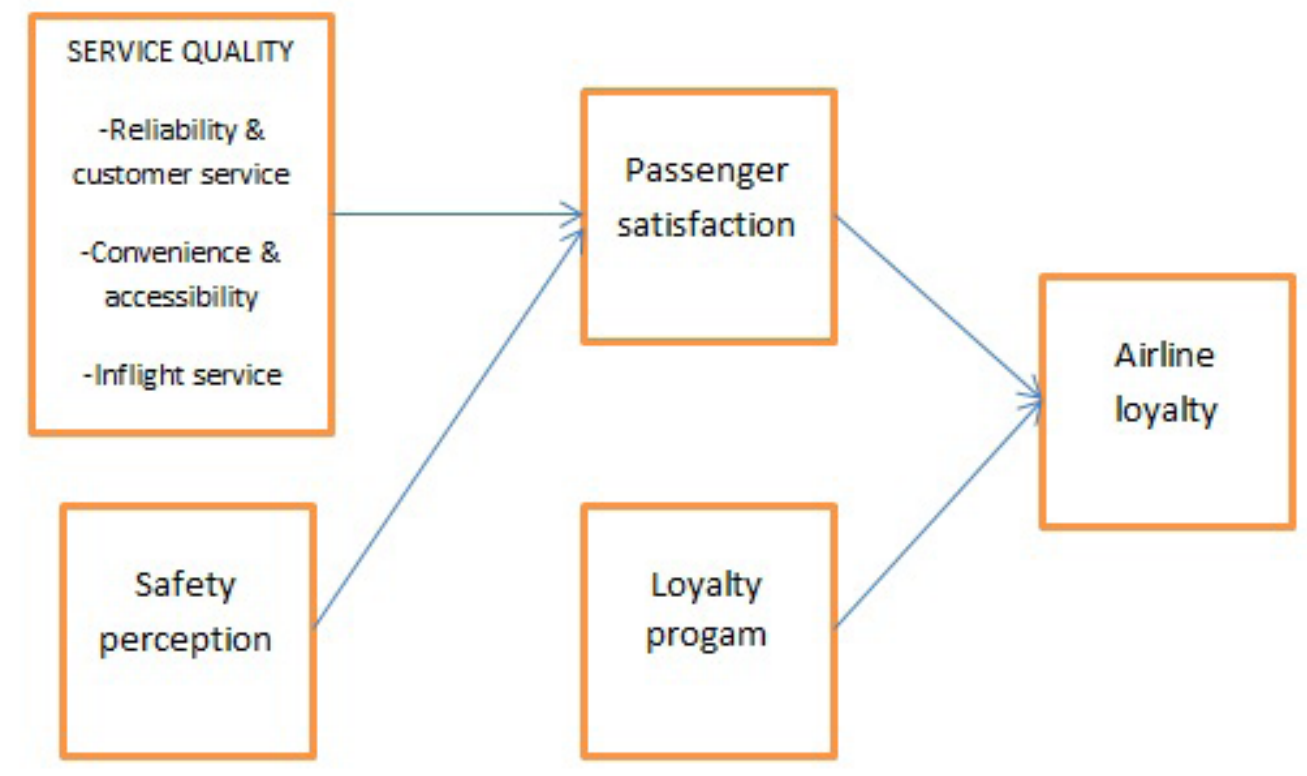

out an empirical study at Harare International airport (HRE) by collecting data from airline passengers who had booked to travel with the airlines under study and admitted to having travelled with the same airline within the previous 12 months. The study focused on routes to international destinations that were exposed to competition to ensure passenger discretion in airline selection. The reasons for choosing HRE for this study are threefold. First, there has been renewed interest in the airport from a number of airlines in the aftermath of the dollarization of the economy in 2009, which brought economic stability and contributed to a steep increase in passenger numbers, which grew by 27\% between 2010 and 2014 (ZimStat, 2015). Secondly, the central location of the airport, which is within three and half hours flight time from the majority of the Southern African capitals, makes it a potential hub for the region.

This study adopted the positivism paradigm because it seeks to prove or disapprove hypotheses developed from existing theories (Saunders et al., 2009). The research was explanatory in nature because it sought to determine the cause and effect relationships between variables. Quantitative data collection techniques were used because data should be quantifiable to facilitate the application of statistical analysis (Malhotra, 2007). A systematic random sampling method was used to select respondents at a sampling interval of five. The study was carried out on five randomly selected days within a two week period in order to randomize data collection. The criteria used for the study was deemed to produce a representative sample to justify statistical inference.

\subsection{Data collection instrument}

A self-administered questionnaire was used as a data collection instrument. The questionnaire design was based on prior studies investigating airline loyalty and behavioral intentions. Service quality was measured using a modified scale developed by Park et al. (2005) by incorporating additional service quality dimensions specific to air travel on the original SERVQUAL scale attributed to the work of Parasuraman et al. (1988). All three dimensions of service quality identified by Park et al. (2005) namely (i) Reliability and customer service, (ii) Convenience and customer service and (iii) In-flight service, were adopted for this study. The measurement dimensions for satisfaction were adopted from Olorunniwo, Hsu and Udo (2006) and Fraering and Minor (2013). Customer loyalty dimensions were adopted from Dehghan and Shahin (2011) and Caruana (2002) and were aimed at evaluating a customer's repurchase intensions, willingness to engage in positive word of mouth and switching behavior. Measurement dimensions for safety perception were derived from earlier studies by Ringle et al. (2011) and Gilbert and Wong (2003). All the questions related to each dimension were measured using 7-point Likert scales.

\section{RESULTS AND DATA ANALYSIS}

\subsection{Sample characteristics}

The profiles of the passengers who participated in the study are shown in Table 1 . The gender distribution was uneven, with more males, $58.8 \%(n=87)$ of 
Table 1: Sample characteristics

\begin{tabular}{|c|c|c|c|}
\hline Attributes & Distribution & Frequency & Percent (\%) \\
\hline \multirow{3}{*}{ Gender } & Female & 61 & 41.2 \\
\hline & Male & 87 & 58.8 \\
\hline & Total & 148 & 100 \\
\hline \multirow{6}{*}{ Age } & 18 to 30 years & 30 & 20.3 \\
\hline & 31 to 40 years & 48 & 32.4 \\
\hline & 41 to 50 years & 38 & 25.7 \\
\hline & 51 to 60 years & 24 & 16.2 \\
\hline & Over 60 years & 8 & 5.4 \\
\hline & Total & 148 & 100 \\
\hline \multirow{6}{*}{$\begin{array}{l}\text { Marital } \\
\text { Status }\end{array}$} & Single & 40 & 27 \\
\hline & Married & 98 & 66.2 \\
\hline & Separated & 1 & 0.7 \\
\hline & Divorced & 5 & 3.4 \\
\hline & Widowed & 4 & 2.7 \\
\hline & Total & 148 & 100 \\
\hline \multirow{7}{*}{$\begin{array}{l}\text { Ethnic } \\
\text { origin }\end{array}$} & African & 99 & 66.9 \\
\hline & European & 35 & 23.6 \\
\hline & Asian & 6 & 4.1 \\
\hline & North American & 5 & 3.4 \\
\hline & Latin American & 1 & 0.7 \\
\hline & Australian & 2 & 1.4 \\
\hline & Total & 148 & 100 \\
\hline \multirow{5}{*}{$\begin{array}{l}\text { Highest } \\
\text { educational } \\
\text { level }\end{array}$} & High School & 11 & 7.4 \\
\hline & Diploma/Higher diploma & 27 & 18.2 \\
\hline & Undergraduate degree & 37 & 25 \\
\hline & Post graduate degree & 73 & 49.3 \\
\hline & Total & 148 & 100 \\
\hline
\end{tabular}

\subsection{Structural Equation Modelling}

To analyze the psychometric properties of the measurement scales and test the hypothesized causal relationships, the Structural Equation Modelling (SEM) procedure suggested by Anderson and Gerbing (1988) was used. According to this procedure, a measurement model was established before the structural model. A confirmatory factor analysis (CFA) was utilized to estimate the measurement model and to ascertain data quality, including a verification of reliability and construct validity (Ali, Dey \& Filieri, 2015). Structural equation modeling was used to test the overall fit of the model and to test the hypothesized causal relationships among the constructs under investigation. The reasons for using the SEM were twofold. First, it is able to estimate several inter-relationships among latent constructs simultaneously in a model. Second, the SEM can efficiently estimate the CFA in the measurement models, analyze the causal relationships of latent constructs in a structural model, calculate their variance as well as covariance, and test hypotheses in the model simultaneously (Ali et al., 2015).

\subsection{Measurement Model}

In order to evaluate convergent validity and discriminant validity, a CFA was carried out. The results indicated a good model fit as advised by Hair et al. (2010) because the chi-square $=13.230 ; \mathrm{df}=19 ; \mathrm{p}=0.000 ; \mathrm{NF} 1$

the respondents, compared to women, $41.2 \%(n=61)$. The majority of the respondents were aged between 31 and 50 years $(58.1 \% ; n=86)$. A fifth of the remaining passengers were below the age of thirty and the rest were above the age of fifty (50). The ethnic composition was skewed towards Africans and Europeans, representing $90.5 \%(n=134)$ of the valid cases. Almost half the respondents $(49.3 \%, n=73)$ indicated that they had completed post-graduate studies and the income levels for all the cases were evenly distributed. The passenger profiles were a fair representation of the travellers and the interview questions were fairly understood.
$=0.940 ; \mathrm{CFI}=0.943 ; 1 \mathrm{~F} 1=0.944$ and $\mathrm{RMSEA}=0.051$. The model was therefore used for further analysis. For convergent validity, the factor loadings of each item, the average variance extracted (AVE) and Cronbach's Alpha coefficient were analyzed. Table 2 shows high factor loadings ranging between 0.701 and 0.842 , which surpassed the minimum threshold of 0.5 ( $\mathrm{Har}$ et al., 2010), thereby demonstrating convergence of the indicators with suitable underlying factors. Table 2 also shows that both the Cronbach alpha coefficients and Composite reliability values were above 0.7 as suggested by Nunnally (1978). Furthermore, the AVE values for individual constructs were all above 0.50 . The general indication is that there is evidence 
Table 2: Confirmatory factor analysis of the model

\begin{tabular}{|c|c|c|c|c|}
\hline Factor & Item & $\begin{array}{l}\text { Standard } \\
\text { loadings }\end{array}$ & $\begin{array}{l}\text { Cronbanch } \\
\text { alpha }\end{array}$ & AVE \\
\hline \multirow{8}{*}{$\begin{array}{l}\text { Service } \\
\text { quality }\end{array}$} & $\begin{array}{l}\text { The employee attitude of airlines demonstrates their willingness to } \\
\text { help me. }\end{array}$ & 0.720 & 0.853 & 0.522 \\
\hline & $\begin{array}{l}\text { The employee attitude of airlines shows me that they understand my } \\
\text { needs. }\end{array}$ & 0.717 & & \\
\hline & $\begin{array}{l}\text { The airline employees are able to handle my complaints directly and } \\
\text { immediately. }\end{array}$ & 0.702 & & \\
\hline & The toilet in the cabin is clean. & 0.810 & & \\
\hline & The airline's facility is well designed. & 0.713 & & \\
\hline & I rarely have to wait long to receive the airline service & 0.842 & & \\
\hline & The airline tells me the accurate time on which it provides service & 0.701 & & \\
\hline & The airline provides me with convenient flight schedules. & 0.772 & & \\
\hline \multirow[t]{2}{*}{ Satisfaction } & I am satisfied with the airline's customer loyalty programmes & 0.767 & 0.892 & 0.511 \\
\hline & I am happy with rewards offered by the reward programme & 0.790 & & \\
\hline \multirow{3}{*}{ Safety } & There are thorough security checks at the airport & 0.752 & 0.791 & 0.587 \\
\hline & I feel safe during the flight & 0.820 & & \\
\hline & The cabin crew members are competent & 0.755 & & \\
\hline \multirow{3}{*}{$\begin{array}{l}\text { Loyalty } \\
\text { programmes }\end{array}$} & Loyalty programmes make me strongly connected to the airline & 0.743 & 0.802 & 0.651 \\
\hline & I fly more frequently on this airline to earn more points & 0.785 & 0.802 & 0.651 \\
\hline & $\begin{array}{l}\text { If an airline does not have a customer loyalty programme I miss out } \\
\text { on benefits }\end{array}$ & 0.840 & & \\
\hline \multirow[t]{3}{*}{ Loyalty } & I intend to continue flying with the airline & 0.724 & 0.853 & 0.611 \\
\hline & I have confidence in recommending the airline to friends and relatives & 0.806 & & \\
\hline & I resist influences for me to switch to other airlines & 0.805 & & \\
\hline
\end{tabular}

Table 3: Discriminant validity

\begin{tabular}{|c|c|c|c|c|c|}
\hline & Service quality & $\begin{array}{l}\text { Loyal/frequent } \\
\text { flyer programmes }\end{array}$ & Safety & Satisfaction & Loyalty \\
\hline Service quality & .723 & & & & \\
\hline $\begin{array}{l}\text { Loyal /frequent flyer } \\
\text { programmes }\end{array}$ & $.223^{* *}$ & .715 & & & \\
\hline Safety & $.665^{* *}$ & .149 & .766 & & \\
\hline Satisfaction & $.692^{* *}$ & .106 & $.605^{* *}$ & .758 & \\
\hline Loyalty & $.600^{* *}$ & $.464^{* *}$ & $.486^{* *}$ & $.586^{* *}$ & .760 \\
\hline
\end{tabular}

to demonstrate the uni-dimensionality, reliability and validity of the measures (Ali et al., 2015). The results of discriminant validity are shown in Table 3. The diagonal in the table indicates that the square root of the AVE between each pair of factors was higher than the estimated correlation between the factors, thereby proving discriminant validity (Hair et al., 2010). The bold diagonal numbers in the table are the square root of the AVE shared between the constructs and their measures, while the remaining numbers are the correlations among the constructs. Overall, the $\mathrm{R}^{2}$ results for passenger satisfaction and passenger loyalty to the airline shown in Table 3 indicate that the research model explains more than $55 \%$ and $50 \%$ respectively of the variance in the endogenous variables. 
Figure 2: Path coefficients

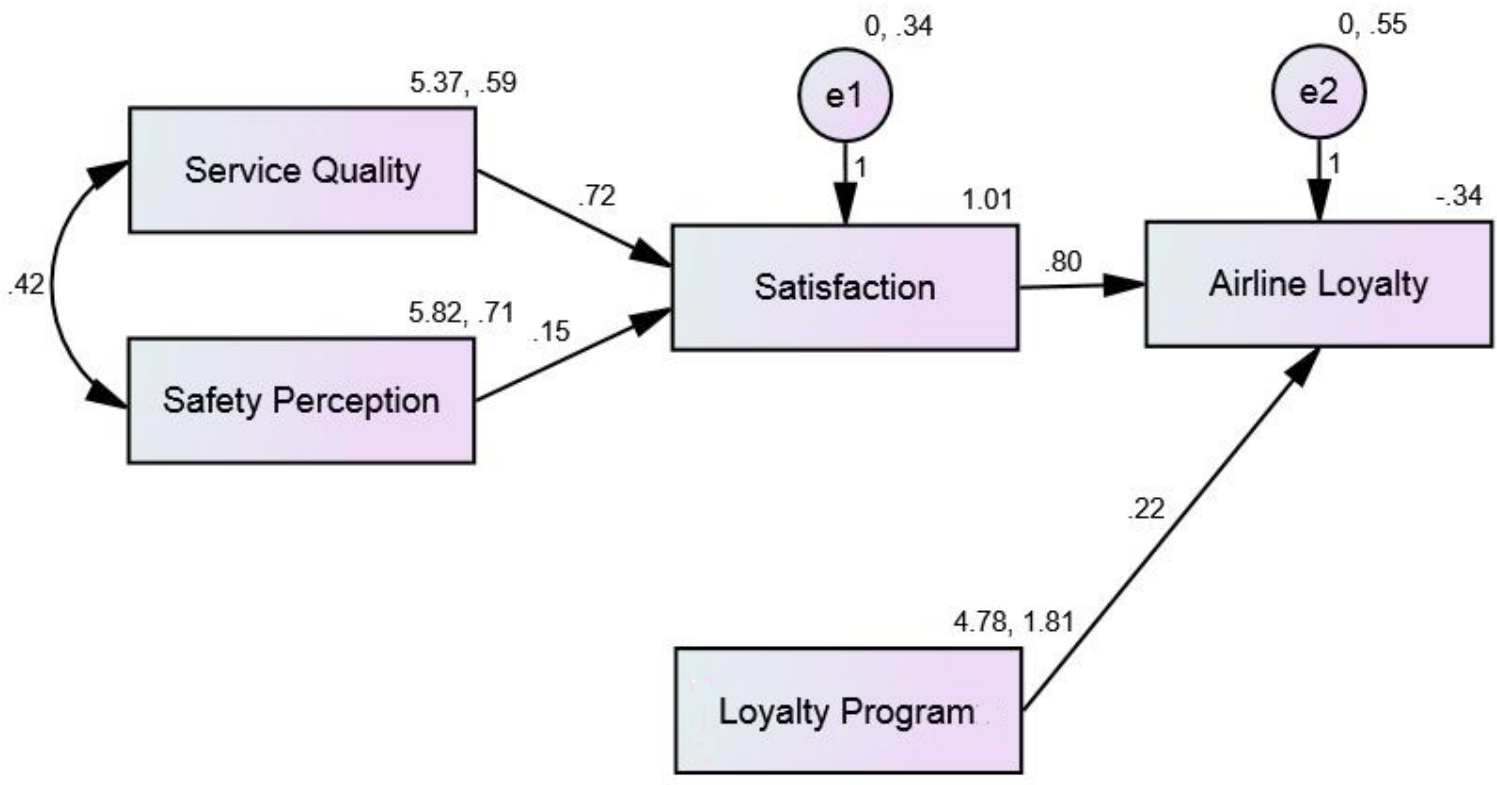

Table 4: Results of structural model

\begin{tabular}{|l|c|c|c|c|}
\hline Hypothesis & $\begin{array}{c}\text { Standardized } \\
\text { coefficients }\end{array}$ & S.E. & p-value & Decision \\
\hline H1 Satisfaction $\longrightarrow$ loyalty & 0.800 & .071 & 0.000 & Supported \\
\hline H2 Service quality $\longrightarrow$ satisfaction & 0.720 & .081 & 0.000 & Supported \\
\hline H3 Frequent flyer program $\longrightarrow$ loyalty & 0.220 & .046 & 0.000 & Supported \\
\hline H4 Safety perception $\longrightarrow$ satisfaction & 0.150 & .074 & 0.039 & Rejected \\
\hline
\end{tabular}

\subsection{Structural model results}

To test the parameters, a structural model of airline service quality, safety reputation, frequent flyer programs (loyalty programs) and passenger loyalty was constructed. The aim of building a structural model was to establish if airline service quality, passenger satisfaction, frequent flyer programs and airline safety reputation have a significant influence over passenger loyalty. The chi-square $=20.859 ; \mathrm{df}=5 ; \mathrm{p}=0.001 ; \mathrm{NF1}$ $=0.937 ; \mathrm{CFI}=0.951 ; \mathrm{GF} 1=0.93$ and $\mathrm{RMSEA}=0.055$ all show that the model was significant. The results of the structural model are shown in figure 2 .

Regarding the structural equations, the results demonstrate that passenger satisfaction has positive effects on passenger loyalty $\left(\beta=0.800^{*}\right)$, airline service quality positively influences passenger satisfaction $\left(\beta=0.720^{*}\right)$, and frequent flyer program/ loyalty programs positively impact passenger loyalty $\left(\beta=0.220^{*}\right)$. Therefore $H 1, H 2$ and $H 3$ are supported. However, the perceived safety of an airline did not exhibit a significant influence on passenger satisfaction ( $\beta=0.150$ ) and thus $H 4$ is rejected. As depicted in Table 4, the standard errors (SE) are very small and this means that the possibility of making errors is minimal. Table 4 presents a summary of the hypotheses testing.

\section{DISCUSSION OF FINDINGS}

The findings confirmed that service quality positively impacts customer satisfaction and satisfaction subsequently influences customer loyalty in the airline industry in Southern Africa. This finding was consistent with the results of studies conducted in 
other parts of the world (Gures et al. 2014; Jan et al. 2013). The implication of this outcome is that managers intending to develop customer loyalty must satisfy customers through the provision of an outstanding service quality experience to passengers. In addition, the findings also confirmed the consumer marketing theory that highly satisfied customers repurchase more and provide positive word of mouth, resulting in improved profitability (Kotler \& Keller, 2012).

Additionally, the research findings confirmed some earlier empirical studies (Lederman ,2007; Lewis, 2004) on the positive impact of FFPs in influencing airline preference and customer loyalty. In light of the opposing views on the usefulness of FFPs in influencing behavioral intentions and customer loyalty it was necessary to drill down further on the relationship between the two variables. By using the part correlations it was evident that FFPs uniquely explained only $6.5 \%$ of the total variance in customer loyalty as opposed to satisfaction, which uniquely contributed $20.3 \%$. The customer loyalty program dimension also recorded the lowest mean score of 4.78 and the highest standard deviation of 1.35 , implying divergent views and low importance attached to this dimension in influencing customer loyalty. FFP should be viewed as a complementary service that can be used to reward an airline's profitable customers as a way of persuading them to remain loyal and create some switching costs for those customers. Contrary to findings by Ringle et al. (2011), safety perception was not a significant determinant of satisfaction, but it was a statistically significant contributor to the prediction of customer loyalty. By utilizing part correlations it was apparent that safety perception uniquely explained only $1.5 \%$ of the total variance in customer loyalty. While the result reached statistical significance it might be of limited practical significance. The possible explanations for this result are twofold. First, it is difficult to assess the safety dimensions of an airline objectively, therefore passengers resort to proxy measures of safety such as an airline's service quality or based on their perceptions of an aircraft's appearance (Rhoades \& Waguespack, 2000). Secondly, this result could be attributed to the fact that all the airlines under study had good safety records and had not been involved in any major disasters since 2011.

\section{MANAGERIAL IMPLICATIONS}

The present study provided some practical implications for marketing managers in the airline industry in Southern Africa. An analysis of the results from the empirical research revealed that all three service quality dimensions were significant drivers of customer satisfaction and that satisfaction subsequently influenced customer loyalty development. Since we already know that loyalty drives profitability (Reichheld, 2001; Oliver, 1997), it is incumbent upon airline managers to develop systematic ways of continuously assessing, monitoring and improving service quality in order to keep customers delighted and make them more loyal to the airline. Airlines should continuously have a finger on the pulse of satisfaction through regular surveys that are designed to measure and track customer satisfaction. Inevitably, drivers of customer satisfaction will continue to change over time as new technologies are introduced and other changes occur in the market place, making it obligatory for airlines to design and set up processes that allow them to quickly respond to changes in the environment. Marketing managers should ensure their airlines deliver the promised service. Social media and online chat forums have made it easier for customers to share experiences and it is to an airline's advantage if the shared experiences are coming from satisfied customers.

Airline cabin crew and all employees working at customer touch points should be provided with exceptional training regularly and be equipped to ensure that they are able to offer outstanding service quality. As alluded to by Kotler and Keller (2012), welltrained personnel are courteous, reliable, competent, credible and responsive. An airline can only promise excellent service to passengers when they are confident that their customer facing staff is able to provide it. Employees deliver the service promise and when they are truly committed to their job, they go the extra mile in order to match or exceed customer expectations, resulting in high levels of satisfaction. Internal marketing is thus an important element of the service marketing toolkit because of the high level of interaction between customers and service personnel.

This study also showed that FFPs and safety perception were determinants of customer loyalty. Safety is a number one priority in aviation (IATA, 2014) and airlines should ensure that flying is safe by investing in staff training, newer equipment and complying with all safety regulations. FFPs should be designed carefully to ensure that the benefits to the airlines outweigh the costs of setting up such programs. FFPs are also a potential source of valuable customer data that can be harnessed by the airlines to provide important insights into their customers' travelling patterns and preferences. Airline marketing managers can utilize 
this information to communicate unique offers, such as price specials or the introduction of value added services such as In-flight Wi-Fi on their frequent routes.

\section{CONCLUSION}

This study investigated the factors that drive customer loyalty in the airline industry in Southern Africa by analyzing the causal relationships between service quality dimensions, safety perception and satisfaction and the subsequent effect of satisfaction and FFP on customer loyalty. The results of multiple regression analysis demonstrated that all service quality dimensions have a significant positive effect on satisfaction and satisfaction subsequently drives customer loyalty, implying that satisfied customers are more likely to continue flying with the same airline in the future, spread positive word of mouth and are less inclined to switch to other airlines. The results also showed that FFP had a positive effect on customer loyalty. The relationship between safety reputation and satisfaction could not be confirmed in the present study. While satisfaction is necessary for the development of loyalty, having satisfied customers on its own is not good enough, making it imperative for airlines to go beyond satisfaction and excite passengers so that they disregard situational influences that could potentially cause switching behavior.

\section{STUDY LIMITATIONS AND AREAS OF FURTHER STUDY}

Inevitably there were a few limitations in this study that point to areas of further investigation in the area of customer loyalty in the airline industry in Southern Africa. First, the study was carried out in only one airport (HRE) that has relatively few airlines and a limited number of direct flights to destinations outside Southern Africa. Future studies can replicate the investigation at bigger airports such as OR Tambo international airport to enhance the generalizability of these findings to all Southern African airports. The second limitation relates to the study timelines and the use of revealed preference (RP) data collected from departing passengers. The study was carried out over a two week period, implying that the results could have been influenced by some one-time events such as flight delays or flight cancellations. Future studies could take the form of longitudinal studies to compensate for short term influences and consider the use of stated preference data in order to provide a validation of the results from the current study.

Another notable limitation of this study relates to the use of service quality dimensions adopted from studies carried out in developed countries. While this approach improves the internal consistency and reliability of the measures, it does not guarantee that all such factors are relevant in a different social and economic setting with passengers from predominantly developing countries. Future studies can explore and investigate the important service quality dimensions for the airline industry in Southern Africa leading to the development of a more refined service quality measurement scale for the airline industry in Southern Africa.

Lastly, this study only considered the impact of airline-specific FFPs on customer loyalty. Future studies on airline loyalty in Southern Africa can also explore whether passengers prefer airline specific FFPs or FFPs for airline alliances. Airline alliances such as One World and Star Alliance broaden the routes coverage for airlines, thus giving frequent fliers more opportunities to earn points and more options for redeeming accumulated points. Future research studies could also further develop the model of this study in order to better explain customer loyalty in the airline industry in the context of Southern Africa. Despite all the limitations that have been identified, the researcher is still confident that this study provided a number of practical guidelines for airline marketing managers and direction for future research.

\section{REFERENCES}

Angelova, B. and Zekiri, J. 2011. Measuring customer satisfaction with service quality using American Customer Satisfaction Model (ACSI Model). International Journal of Academic Research in Business and Social Sciences. 1 (3): 232-258.

All, F., Dey, B.L. and Filieri, R. 2015. An assessment of service quality and resulting customer satisfaction in Pakistan International Airlines: Findings from foreigner and overseas Pakistani cusotmers. International Journal of Quality and Reliability Management 32 (5): 486-502.

Bartlett, M., 1954. A note on the multiplying factors for various chi square approximations. Journal of the Royal Statistical Society 16: 296-298.

Basso, L.J., Clements, M.T. and Ross, T.W., 2009. Moral Hazard and Customer Loyalty Programs. American Economic Journal: Microeconomics 1 (1): 101-123.

Bowen, J.T. and Chen, S.-L., 2001. The relationship between customer loyalty and customer satisfaction. International 
Journal of Contemporary Hospitality Management 13 (5): 213-217.

CAPA, 2012. Airline profitability prospects improve but profit margins remain anaemic. Aviation Analysis. http:// centreforaviation.com/analysis/airline-profitabilityprospects-improve-but-profit-margins-remain-anaemic-85722 (accessed April 9, 2015).

Carlsson, F. and Lofgren, A. 2006. Airline choice, switching costs and frequent flyer programmes. Applied Economics 1469-1475.

Caruana, A. 2002. Service loyalty:The effects of service quality and the mediating role of customer satisfaction. European Journal of Marketing 36 (7/8): 811-828. http://www. emeraldinsight.com/10.1108/03090560210430818 (Accessed July 11, 2014).

Chandrashekaran, M. et al. 2007. Satisfaction Strength and Customer Loyalty. Journal of Marketing Research 44 (1): 153-163.

Cheema, J.R., 2014. Some General Guidelines for Choosing Missing Data Handling Methods in Educational Research. Journal of Modern Applied Statistical Methods. 13 (2): pp.53-75.

Cheng, B. and Rashid, Z.A. 2013. Service Quality and the Mediating Effect of Corporate Image on the Relationship between Customer Satisfaction and Customer Loyalty in the Malaysian Hotel Industry. International journal of Business 15 (2): 99-112.

Davis, M.M. and Heineke, J. 1998. How disconfirmation, perception and actual waiting times impact customer satisfaction. International Journal of Service Industry Management 9 (1): 6473.

Dehghan, A. and Shahin, A. 2011. Customer Loyalty Assessment: A Case Study in MADDIRAN, the Distributor of LG Electronics in Iran. Journal of Business Management and Strategy 2 (1): 1-23.

Divett, M., Crittenden, N. and Henderson, R., 2003. Actively influencing consumer loyalty. Journal of Consumer Marketing 20 (2): 109-126.

Dolnicar, S. et al. 2011. Key drivers of airline loyalty. Tourism Management 32 (5): 1020-1026.

Dowling, G., 2002. Customer Relationship Management: IN B2C MARKETS, OFTEN LESS IS MORE. California Management Review 44 (3): 87-104.

Eggert, A. and Ulaga, W. 2002. Customer perceived value: a substitute for satisfaction in business markets. Journal of Business \& Industrial Marketing 2-3 (17): 107-118.

Faizan, A., Bidit, L.D. and Raffaele, F. 2015. An assessment of service quality and resulting customer satisfaction in Pakistan International Airlines: Findings from foreigners and overseas Pakistani customers. International Journal of Qouality \& Reliability Management 32 (5): 486-502. http://dx.doi.org/10.1108/IJQRM-07-2013-0110
Fraering, M. and Minor, M.S. 2013. Beyond loyalty : customer satisfaction, loyalty, and fortitude. Journal of Services Marketing 27 (4): 334 - 344.

Gilbert, D. and Wong, R.K.. 2003. Passenger expectations and airline services: a Hong Kong based study. Tourism Management 24 (5): 519-532.

Gómez, G.B., Arranz, G.A. and Cillán, G.J. 2006. The role of loyalty programs in behavioral and affective loyalty R. C. Levanthal. Journal of Consumer Marketing 23 (7): 387-396. http://www.emeraldinsight.com/doi/ abs/10.1108/07363760610712920 (accessed December 8, 2014).

Gounaris, S. and Stathakopoulos, V. 2004. Antecedents and consequences of brand loyalty: an empirical study. Journal of Brand Management 11 (4): 283-306.

Grönroos, C. 1982. Strategic Management and Marketing in the Service Sector. Swedish School of Economics and Business Administration.

Gures, N., Arslan, S. and Tun, Y.S. 2014. Customer Expectation, Satisfaction and Loyalty Relationship in Turkish Airline Industry. International Journal of Marketing Studies 6 (1): 66-74. http://www.ccsenet.org/journal/index.php/ ijms/article/view/31920 (accessed January 5, 2015).

Hair, J.F., Black, W.C., Babin, B.J. and Anderson, R.E. 2010. Multivariate data analysis. Prentice Hall, Upper Saddle River, NJ.

Hair, J.F., Bush, R.P. and Ortinau, D.J. 2000. Marketing research: a practical approach for the new millennium. Singapore: McGraw Hill.

Han, X., Kwortnik, R.J. and Wang, C. 2008. Service loyalty: An integrative model and examination across service contexts. Journal of Service Research 11: 22-42.

Heskett, J.L., Jones, T.O., Loveman, G.W., Sasser, E.W. and Schlesinger, L.A. 1994. Putting the service-profit chain to work. Harvard Business Review 72 (2): 164-174.

Hess, S., Adler, T. and Polak, J.W. 2007. Modelling airport and airline choice behaviour with the use of stated preference survey data. Transportation Research Part E 43 (3): 221-233. http://dx.doi.org/10.1016/j.tre.2006.10.002

Huppertz, J.W., Arenson, S.J. and Evans, R.H. 1978. An Application of Equity Theory to Buyer-Seller Exchange Situations. Journal of Marketing Research 15 (2): 250-260.

Airlines Internationa. IATA, 2014 70th IATA Annual General Meeting and World Air Transport Summit in Doha, Qatar. Tony Tyler's State of the Industry, keynote speech. http://www.iata.org/pressroom/speeches/ Pages/2014-06-02-1.aspx.

Jan, M.T., Abdullah, K. and Smail, M.H. 2013. Antecedents of Loyaltyin the Airline Industry of Malaysia :An Examination of Higher-Order Measurement Model. Proceedings 3rd Asia-Pacific Business Research Conference, 25 - 26 February 2013, Kuala Lumpur, Malaysia: 1-14. 
Kaiser, H., 1974. An index of factorial simplicity. Psychometrika 39: 31-36.

Kandampully, J. and Hu, H., 2007. Do hoteliers need to manage image to retain loyal customers? International Journal of Contemporary Hospitality Management 19 (6): 435-443. http://www.emeraldinsight.com/doi/ abs/10.1108/09596110710775101 (accessed January 23, 2015).

Kandampully, J. and Suhartanto, D. 2000. Customer Loyalty in the hotel industry: the role of customer satisfaction and image. International Journal of Contemporary Hospitality Management 12 (6): 346-351.

Keaveney, S.M. 1995. Customer Switching Behavior in Service Industries: An Exploratory Study. Journal of Marketing 59:71-82.

Kotler, P. and Keller, K.L. 2012. Marketing Management (14th ed.). Upper Saddle River, NJ: Pearson Education Inc. Prentice Hall

Lacey, R. and Sneath, J. 2006. Customer loyalty programs: are they fair to consumers? Journal of Consumer Marketing 7 (23): 458-464.

Lederman, M., 2007. Do enhancements to loyalty programs affect demand? The impact of international frequent flyer partnerships on domestic airline demand. The RAND Journal of Economics 38 (4): 1134-1158.

Lemon, K.N., White, T.B. and Winer, R.S. 2002. Dynamic Customer Relationship Management: Incorporating Future Considerations into the Service Retention Decision. Journal of Marketing 66:1-14.

Lewis, M., 2004. The Influence of Loyalty Programs and Short-Term Promotions on Customer Retention. Journal of Marketing Research 41 (3): 281-292.

Lewis, R.C. and Booms, B.H. 1983. The marketing aspects of Service quality. In Berry, L.L, Shostack, G. \& Upah, G. (Eds). Emerging perspectives on Services Marketing. American Marketing Association, Chicago, IL: 99-107.

Liu, Y., 2007. The Long-Term Impact of Loyalty Programs on Consumer Purchase Behavior and Loyalty. Journal of Marketing 71 (4): 19-35.

Lovelock, C. and Wirtz, J. 2010. Services Marketing - People, Technology, Strategy. (7th ed.). Prentice Hall.

Malhotra, N.K., 2007. Marketing Research: An applied orientation. (7th ed.). Englewood Cliffs, NJ: Prentice Hall.

Meyer-Waarden, L., 2008. The influence of loyalty programme membership on customer purchase behaviour. Euroepan Journal of Marketing 42 (1/2): 87-114.

Mittal, B. and Lassar, W.M. 1998. Why do customers switch? The dynamics of satisfaction versus loyalty. Journal of Services Marketing 12 (3): 177-194.

Oliver, R.L., 1997. Satisfaction: A behavioural perspective on the consumer. New York NY: Irwin-McGraw Hill.

Oliver, R.L., 1999. Whence Consumer Loyalty? Journal of Marketing 63:33-44. http://www.jstor.org/ stable/1252099?origin=crossref.
Olorunniwo, F., Hsu, M.K. and Udo, G.J. 2006. Service quality, customer satisfaction, and behavioral intentions in the service factory. Journal of Services Marketing 20 (1): 59-72.

Ostrowski, P.L., O'Brien, T. and Gordon, G.L. 1993. Service quality and customer loyalty in the commercial airline industry. Journal of Travel Research 32 (1): 16-24.

Oyewole, P., Sankaran, M. and Choudhury, P. 2007. Consumer Choice of Airlines in Malaysia: A Synthesis of Perspectives from Participants in the Air Travel Market. Journal of International Consumer Marketing 20 (1): 19-31.

Pallant, J., 2005. SPSS survival manual: a step by step guide to data analysis using SPSS for Windows. Crows Nest, Australia: Allen \& Unwin.

Parasuraman, A., Zeithaml, V.A. and Berry, L.L. 1985. A Conceptual model of service Quality and its Implications for Future Research. Journal of Marketing 49:41-50.

Parasuraman, A., Zeithaml, V.A. and Berry, L.L., 1988. SERVQUAL: A multiple-item scale for measuring customer perceptions of service quality. Journal of Retailing 1 (64): 12-40.

Park, J., Robertson, R. and Cheng-Lung, W. 2005. Investigating the Effects of Airline Service Quality on Airline Image and Passengers' Future Behavioural Intentions : Findings from Australian international air passengers. The Journal of Tourism Studes 16 (1): 2-11.

Peppers, D. and Rogers, M. 2005. Customers Don't Grow on Trees. Fast Company. July: 25-26.

Reichheld, F. and Teal, T. 1996. The Loyalty Effect:The Hidden Force Behind Growth, Profits, and Lasting Value. Boston, Massachusets: Harvard Business School Press.

Reichheld, F.F. 2001. Loyalty Rules! How Today's Leaders Build Lasting Relationships. Boston, Massachusetts: Harvard Business School Press.

Rhoades, D.L. and Waguespack, B.J. 2000. Judging a book by its cover : the relationship between service and safety quality in US national and regional airlines. Journal of Air Transport Management 6 (2): 87-94.

Ringle, C.M., Sarstedt, M. and Zimmermann, L. 2011. Customer satisfaction with commercial airlines: The role of perceived safety and purpose of travel. Journal of Marketing Theory and Practice 19 (4): 459-472.

Saunders, M., Lewis, P. and Thornhill, A. 2009. Research methods for business students (5th ed.). Harlow, Essex; Pearson Education Limited. Prentice Hall

Seiders, K., Boss, B.G., Grewal, D. and Godfrey, L.A. 2005. Do Satisfied Customers Buy More? Examining Moderating Influences in a Retailing Context. Journal of Marketing 69 (4): $26-43$.

Streiner, D.L. 2003. Being inconsistent about consistency: When coefficient alpha does and doesn't matter. Journal of Personality Assessment 80 (3): 217-222.

Szczepańska, K. and Gawron, P.P. 2011. Changes in Approach to Customer Loyalty. Contemporary Economics 5 (1): 10. 
http://ce.vizja.pl/en/download-pdf/id/202

(accessed January 7,2015$)$.

Tepeci, M., 1999. Increasing brand loyalty in the hospitality industry. International Journal of Contemporary Hospitality Management 11 (5): 223-230.

Thaler, R. 2008. Mental Accounting and Consumer Choice. Marketing Science 27 (1): 15-25.

Tibachnick, B.G. and Fidel, L.S. 2001. Using Multivariate Statistics (4th ed.). New York: HarperCollins.

Tse, D.K. and Wilton, P.C. 1988. Models of Consumer Satisfaction Formation: An Extension. Journal of Marketing Research, 25 (2): 204-212.

Uncles, M.D., Dowling, G.R. and Hammond, K. 2003. Customer loyalty and customer loyalty programs. Journal of Consumer Marketing 20 (4): 294-316.
Wessels, D. 2006. Consumer Loyalty in the Airline Industry. Philadelphia PA: The Whartong School of the University of Pennsylvania.

Wong, A. and Sohal, A. 2003. A critical incident approach to the examination of customer relationship management in a retail chain: an exploratory study. Qualitative Market Research: An International Journal 6 (4): 248-262. http://www.emeraldinsight.com/doi/ abs/10.1108/13522750310495337 (accessed February 11, 2015).

ZimStat - Zimbabwe National Statistic Agency. 2015. Facts and Figures 2014. http://www.zimstat.co.zw/sites/default/files/img/publications/Other/FACT_2014.pdf (accessed February 11 2015) 